\title{
Erratum to: A protocol for a systematic review of the diagnostic accuracy of blood markers, synovial fluid, and tissue testing in periprosthetic joint infections (PJI)
}

\author{
Paul E. Beaule ${ }^{1}$, Beverley Shea², Hesham Abdelbary ${ }^{1}$, Nadera Ahmadzai ${ }^{2 *}$, Becky Skidmore², Ranjeeta Mallick ${ }^{3}$, \\ Brian Hutton', Alexandra C. Bunting ${ }^{4}$, Julian Moran ${ }^{5}$, Roxanne Ward ${ }^{2}$ and David Moher ${ }^{2,6}$
}

\section{Erratum}

Following publication, it was noticed that there was a reference missing in this article [1]. Regarding the italicised text below from section Statistical analyses and evidence synthesis of the original article:

We will compare index tests against each other using one of the two approaches (depending on the available data) suggested by the Cochrane Handbook for Diagnostic Test Accuracy Reviews [34].

Both the bivariate model and HSROC model can be used to investigate the relative accuracy of two index tests depending on the nature of the available data (common or variable threshold). We will run both the hierarchical models in SAS software according to the methods of Macaskill et al. as described in the Cochrane Handbook for Diagnostic Test Accuracy Reviews [34].

Reference number 34 should in fact be the reference below:

Macaskill P, Gatsonis C, Deeks JJ, Harbord RM, Takwoingi Y. Chapter 10: Analysing and Presenting Results. In: Deeks JJ, Bossuyt PM, Gatsonis C (editors), Cochrane Handbook for Systematic Reviews of Diagnostic Test Accuracy Version 1.0. The Cochrane Collaboration, 2010. Available from: http://srdta.cochrane.org/.

Additionally, Dr Abdelbary's surname included a typographical error. The correct spelling is: Abdelbary. The updated author list is therefore as follows:

Paul E. Beaule, Beverley Shea, Hesham Abdelbary, Nadera Ahmadzai, Becky Skidmore, Ranjeeta Mallick, Brian Hutton, Alexandra C. Bunting, Julian Moran, Roxanne Ward and David Moher.

\footnotetext{
* Correspondence: nahmadzai@ohri.ca

${ }^{2}$ Knowledge Synthesis Group, Ottawa Hospital Research Institute, Center for Practice-Changing Research, 501 Smyth Rd., Ottawa, ON K1H 8L6, Canada Full list of author information is available at the end of the article
}

\begin{abstract}
Author details
${ }^{1}$ Division of Orthopaedic Surgery, University of Ottawa, 501 Smyth Rd., Ottawa, ON K1H 8L6, Canada. ${ }^{2}$ Knowledge Synthesis Group, Ottawa Hospital Research Institute, Center for Practice-Changing Research, 501 Smyth Rd., Ottawa, ON K1H 8L6, Canada. ${ }^{3}$ Ottawa Hospital Research Institute, 501 Smyth Rd., Ottawa, ON K1H 8L6, Canada. ${ }^{4}$ University of Ottawa Faculty of Medicine, 451 Smyth Rd., Ottawa, ON K1H 8L1, Canada. ${ }^{5}$ Bruyère Research Institute, 85 Primrose Ave., Ottawa, ON K1R 6M1, Canada. ${ }^{6}$ School of Epidemiology, Public Health and Preventive Medicine, Faculty of Medicine, University of Ottawa, Ottawa, ON, Canada.
\end{abstract}

Received: 10 June 2016 Accepted: 10 June 2016

Published online: 20 June 2016

\section{Reference}

1. Beaule PE, Shea B, Abdelbary H, Ahmadzai N, Skidmore B, Mallick R, Hutton B, Bunting A, Moran J, Ward R and Moher D. A protocol for a systematic review of the diagnostic accuracy of blood markers, synovial fluid, and tissue testing in periprosthetic joint infections (PJI). Systematic Reviews. 2015;4:148.
Submit your next manuscript to BioMed Central and we will help you at every step:

- We accept pre-submission inquiries

- Our selector tool helps you to find the most relevant journal

- We provide round the clock customer support

- Convenient online submission

- Thorough peer review

- Inclusion in PubMed and all major indexing services

- Maximum visibility for your research

Submit your manuscript at www.biomedcentral.com/submit
Biomed Central 